\title{
Vulnerability, hysteria and fear - conquering Ebola virus
}

\section{The largest ever outbreak of Ebola virus disease is continuing, but good infection control minimises the risk to Australia}

\section{ince the current International Health}

Regulations were implemented in 2007, the

World Health Organization has declared only three events to be public health emergencies of international concern: the 2009 H1N1 influenza pandemic, the recent resurgence of polio and, now, the Ebola virus disease (EVD) outbreak in West Africa. ${ }^{1}$

The species circulating in West Africa, Zaire ebolavirus, carries the highest mortality of the five known species of the genus Ebolavirus. ${ }^{2}$ Symptoms of EVD include fever, myalgia, severe diarrhoea and vomiting and, in some instances, internal and external haemorrhaging. Beyond the medical emergency, affected communities face significant disruption to their lives and livelihoods. Impacts documented in the current outbreak include stigmatising of people who are suffering from or have recovered from the disease, and food insecurity due to quarantined villages being unable to plant or harvest produce.

Ebola virus is transmitted via direct contact with blood, other bodily fluids or contaminated fomites. ${ }^{3}$ Spillover from animals into humans typically occurs through hunting, butchering and consumption of

Sources of information on Ebola virus disease from Australian federal and state health departments

Australia

Australian Government Department of Health. Ebolavirus disease (EVD) outbreaks in West Africa. http://www.health.gov.au/internet/ main/publishing.nsf/Content/ohp-ebola.htm

\section{New South Wales}

NSW Health. Ebola virus disease. http://www.health.nsw.gov.au/ Infectious/alerts/Pages/EVD.aspx

Victoria

Department of Health, Victoria. Ebola virus disease (EVD) in West Africa. http://www.health.vic.gov.au/chiefhealthofficer/alerts/alert2014-07-ebola-virus-disease.htm

\section{Queensland}

Queensland Health. Viral haemorrhagic fevers (quarantinable).

http://www.health.qld.gov.au/cdcg/index/vhf.asp

\section{Western Australia}

Department of Health, Western Australia. Viral haemorrhagic fevers (Crimean-Congo, Ebola, Lassa, Marburg). http://www.public.health. wa.gov.au/3/363/3/viral_haemorrhagic_fevers_crimeancongo_ ebola_lassa.pm

\section{South Australia}

SA Health. Ebola outbreak a public health emergency of international concern. http://www.sahealth.sa.gov.au/ $\mathrm{wps} / \mathrm{wcm} / \mathrm{connect} /$ public+content/sa+health+internet/ protecting+public+health/alerts/health+alerts/ebola+outbreak+a+ public+health+emergency+of+international+concern
Arinjay Banerjee

Siobhan M Mor

BVSc, PhD, MANZCVS

tecturer

Jen Kok
MBBS, FRACP, FRCPA

Medical Virologist ${ }^{1,3}$

Tania C Sorrell

MBBS, MD, FRACP

Director and Professor?

Grant A Hill-Cawthorne MBBChir, MA, MRCP Lecturer in Communicable

Disease Epidemiology $y^{1,4}$

1 Marie Bashir Institute for Infectious Diseases and Biosecurity,

University of Sydney,

Sydney, NSW.

2 Farm Animal and Veterinary Public Health,

University of Sydney, Sydney, NSW.

3 Centre for Infectious Diseases and Microbiology, Westmead Hospital Sydney, NSW.

4 School of Public Health, University of Sydney, Sydney, NSW.

grant.hill-cawthorne@ sydney.edu.au

doi: 10.5694/mjal4.01151 bushmeat (especially primates), as well as possible transmission from bats. ${ }^{4}$ Human-to-human transmission follows when people care for patients or infected family members or participate in traditional burial practices. ${ }^{5}$ Health care workers who have close contact with patients in the absence of strict infection control measures are at significant risk.

The first known outbreak of EVD occurred simultaneously in the Democratic Republic of Congo and Sudan in 1976, culminating in over 600 cases and a case-fatality rate (based on identified cases) in excess of $70 \%$. Since then, several outbreaks have been identified in humans and other primates in Central and East Africa. ${ }^{4}$ The current EVD outbreak in West Africa, where outbreaks have not previously been identified, is the largest recorded. In this outbreak, early cases of EVD went unrecognised as health care workers not familiar with the disease assumed it to be Lassa or yellow fever (both endemic in the region) or malaria. Recent serosurveys suggest that Ebola virus, either Zaire ebolavirus or Bundibugyo ebolavirus, may have been circulating in Sierra Leone as early as $2006 .{ }^{6}$ What led to the spread of the virus so far west is uncertain. Possibilities include transmission by bats, transportation, an infected traveller, or handling and consumption of bushmeat. $^{2}$

In an unprecedented development, the WHO has endorsed the use of experimental drugs in the current outbreak, although these are in short supply. ${ }^{7}$ Hence, control efforts are focused on patient isolation, infection control practice and communication of risk reduction messages in affected communities. Anthropologists have been deployed to provide culturally appropriate responses through better understanding of local customs and perceptions. For instance, in the 2000 Uganda outbreak, isolation areas were initially surrounded with opaque tarpaulins to protect patient privacy, with deceased patients being immediately placed in bags and disposed of rapidly. From the local perspective, ill people would disappear into the isolation units, never to be seen again, and family members were denied the right to grieve according to tradition. Adapting to this information, medical teams removed the tarpaulins so that family members could see their relatives and escort their bodies to the burial grounds. ${ }^{8}$

Outside West Africa, there are concerns that the virus will spread via an infected traveller arriving at an international airport. Australia is well prepared for such a possibility. The Australian Government Department of Health provides extensive guidance for the public, health care professionals and laboratories, and risk assessment guidelines and management 
algorithms have been issued by state departments of health (Box). The diagnosis of EVD should be considered in at-risk patients (defined as those with fever and history of travel to an affected area within 21 days of onset) and expert medical advice sought. At-risk patients should be isolated in single rooms with their own bathroom. Health care workers should use personal protective equipment and take appropriate precautions when collecting samples for laboratory testing or when undertaking aerosolgenerating procedures. ${ }^{9}$ If these procedures cannot be avoided, precautions should include use of P2 respirators, nursing the patient in a negative pressure single room, advising the patient on respiratory hygiene and cough etiquette, ensuring good hand hygiene before and after contact with the patient and the environment, and obtaining expert infection control advice.

The likelihood of EVD is greater in people who have been in contact with anyone with confirmed EVD (or their bodily fluids), or who present with severe vomiting and/or diarrhoea or internal and external bleeding. Advice should be sought immediately from the relevant health department and medical personnel, and protocols for transfer of highrisk patients to quarantine isolation units followed.

The risk to Australia remains small; no cases of EVD have been documented here. However, continued vigilance for patients who fit the case definition, followed by their prompt isolation, is

essential to prevent potential local transmission of the disease. While Ebola virus is a scary proposition, with good infection control and vigilant health authorities, outbreaks will not occur in this country. Instead, we need to focus our efforts on assisting the global response to the crisis in West Africa.

Competing interests: No relevant disclosures.

continued vigilance for patients who fit the case definition, followed by their prompt isolation, is essential
Provenance: Commissioned; externally peer reviewed.

1 World Health Organization. WHO statement on the meeting of the International Health Regulations Emergency Committee regarding the 2014 Ebola outbreak in West Africa [media statement]. 8 Aug 2014. http://www.who.int/mediacentre/news/statements/2014/ ebola-20140808/en (accessed Aug 2014).

2 Vogel G. Infectious disease. Are bats spreading Ebola across sub-Saharan Africa? Science 2014; 344: 140.

3 Muyembe-Tamfum JJ, Mulangu S, Masumu J, et al. Ebola virus outbreaks in Africa: past and present. Onderstepoort J Vet Res 2012; 79: 451.

4 Li YH, Chen SP. Evolutionary history of Ebola virus. Epidemiol Infect 2014; 142: 1138-1145.

5 World Health Organization. Ebola virus disease [fact sheet]. April 2014. http://www.who.int/mediacentre/factsheets/fs103/en (accessed Aug 2014).

6 Schoepp RJ, Rossi CA, Khan SH, et al. Undiagnosed acute viral febrile illnesses, Sierra Leone. Emerg Infect Dis 2014; 20: 1176-1182.

7 World Health Organization. Ethical considerations for use of unregistered interventions for Ebola virus disease (EVD) [media statement]. 12 Aug 2014. http://www.who.int/mediacentre/news/statements/2014/ebolaethical-review-summary/en (accessed Aug 2014).

8 Hewlett BS, Hewlett BL. Ebola, culture and politics: the anthropology of an emerging disease. Belmont, Calif: Thompson Wadsworth, 2008.

9 National Health and Medical Research Council. Australian guidelines for the prevention and control of infection in healthcare. Canberra: Commonwealth of Australia, 2010. http://www.nhmrc.gov.au/guidelines/ publications/cd33 (accessed Aug 2014). 